\title{
GENERATIVE CREATING OF SACRAL SPACE: LATVIAN ANCIENT AND CONTEMPORARY PLACES OF WORSHIP
}

\author{
Silvija Ozola \\ Riga Technical University, Latvia
}

\begin{abstract}
The Balts received God's counsel and energy and regained health in energetically strong places but the Latvian worldview formed on the thousands of years was encoded in the Lielvārde belt, which is Latvian womenfolk costume's element. Bishop (1199-1229) Albert founded the town of Riga for the Riga Bishopric centre on the right bank of the Daugava.It was the four-part Riga Old Town semicircledivided by two main streets as the cross.Soon after the Great Fire in 1214, the construction ofthe Riga Cathedralbegan tocreate sacral urban space in areasof the Old Town and the New Town of Riga (in nova civitate Rige).Now, eastwards of Lielvārde, landscape artist Shunmyō Masuno from Japan has visualized the Garden of Destiny, where people obtainsolace to the past, strength to the present and inspiration to follow dreams in the future. Through this set of relationships, architecture maintains the cosmological connection and dialogue with all the scales of the World. Research object: Latvian places for the worship of God.Research goal: analysis of Latvian urban sacral space. Research problem: common and different features of the sacral space of the Latvians and other nations have been little studied. Research novelty: detailed studies of generative design of sacral spaces and contemporary places of worship in Latvia. Research methods: analysis of archive documents, cartographic and urban planning materials, a study of published literature and inspection of sacral places in nature.
\end{abstract}

Keywords: architecture, evolution, generative language, human life quality, place of worship, sacral space, urban environment.

\section{Introduction}

Latvian wisdomis based on the revelation of God and the creative exploration of the Universe.God is the foundation of all moral values and the origin of all events, and God is understood as the cosmic intelligence that through the laws of nature rules the Universe. God is one for allbut where is this infinite God? God is everywhere: in the middle of the yard, on the side of the road, in the bushes by the road, behind the hill, even under the grey stone. Latvian folk songs, signs and symbols tell about the manifestation of God in the Universe, nature and man - about a unified vision, where God is a person's helper, travel companion and counsellor. In the Latvian understanding of God, man and God are united, because God's part in man is the soul. When a man dies, it returns to God in his 
origin. One of the phenomena is the rotational movement. Each cyclic thing has its own beginning, middle and end, and any cyclic phenomenon starts at a point, spreads, expands and develops, then compresses, shrinks and disappears again at the point. Such picture applies to the life of one person (microcosm) and also the Universe (macrocosm) but the beginning and endpoints never coincide: they are always shifted in time.The cyclic motion in a flat two-dimensional world, or in the plane, occurs in a circle. The circle or cross that shrinks at a single beginning and end point loses dimension and disappears into a single background of consciousness. Our distant ancestors felt the rhythms of the Universe and nature in and around themselves. Dependence on nature prompted people to realize the sky - the Sun and stars. The first cosmological notions related to the cyclicality of cosmic and natural events were formed and expressed in forms that are equally numerical, geometric and aesthetic. The place of man in the Universe was realized. The idea of the symmetrical vertical three-part structure of the World was formedand the man was in its centre. Ancient religion affirms the unity of man and space, as well as the principle that characterizes the Indo-Europeans but especially the Balts, and it is related to the understanding of man's place in all events in God's World time-space.Perceived in time, the man also expressed the felt biological and social rhythms in material and space. The ancient Latvians arranged their homes as small, symbolic areas of the Universe.Spiritually mastered and arranged space combined micro and macro space. The IndoEuropeans and the Balts had a common understanding of sacred space characterized by the horizontal four-part structure of heavenly sides and the threepart vertical structure - heaven-earth-underworld. Constructive logic points to the possibilities of symbolic connection, influences and sometimes determines the sacred meaning, but in the sense of the unity of man and nature, and man and God, the principle of wholeness manifests itself, and it calls to perceive composition as a unified worldview. Man, society, nature, the understanding of the Universe and God, and space fit into a single system, where there is harmony, interaction and balance of all elements. The character of a Latvian has developed closely related to nature and historical conditions. One of the main values of the Latvian mentality is the sovereignty of the individual. A Latvian person is not conservative but is prudent. Prudence is also justified in the strategy: any new trend or impression from the outside is accepted only if it is real, true and understandable to the Latvian soul and complements the Latvian understanding of the World.

There are no high mountains and gigantic waterfalls in the Latvian landscape, and also there are no deserts and steppe plains up to the horizon. In Latvian nature, there seems to be no general degree and extreme contrast. Nature strives for proportionality and balance. Small plains are replaced by hills and forests. The water-rich rivers and many lakes, swamps, forests, as well as the Baltic Sea with its sandy coast, make the climate of the northern land mild and 
temperate. Not every part of the globe has as much wealth as four different seasons. A unique phenomenon is that a large number of quite different microclimates and micro-landscapes can be found in a relatively small area of Latvia, and a great diversity of flora and fauna, which is rare elsewhere in the world, is also concentrated here. The environment has its own structure and its own mythical origin. There are many energetically strong places in Latvia:the positive energy is very well absorbed by water and concentrated by rocks and tectonic elements such as valleys, reliefs, cracks, caves, springs. In nature, everything is interconnected, including ancient Latvian shrines.In energetically strong places near rocks, sacred trees and groves, members of the Balts received God's counsel and energy, and regained health.Religious ritual was connected by concepts the Place, the Way and the Symbol.

In Europe, Pope of Rome and the Holy Roman Emperor started to spread Christianity, andecclesiastical states or bishoprics and towns were founded on the Southern Coast of the Baltic Sea by the mid- $12^{\text {th }}$ century. Bishop (1199-1229) Albert relocated his residence to Riga in 1201, and the city became a site where generative creating of sacral space began, and each one can be able to contribute with own vision, own performing acts, own projects and own dreams.

Research problem: common and different features of sacral space of the Latvians and other nations have been little studied.Research goal: analysis of sacral space creating in Latvian urban environment.Research methods:analysis of archive documents, cartographic materiāls and projects of urban planning, a study of published literature, an inspection of sacral places in nature. This research is based on observation, descriptive and comparative methods of analysis.

\section{The Early Architectural Development of Sacral Space in Latvian Urban Environment}

The origin of Riga developed in the vicinity of the Riga Gulf was related to the Daugava-Dnieper Waterway, which was important for transit trade. It united the distant western and eastern lands. In the $10^{\text {th }}$ to $11^{\text {th }}$ centuries, only the Great Sand Road provided land transport on a peninsula protected from winds and floodplains: one branch led to the port created by a deep bay of the Riga River (Riga rivus, flumen), but the other - to the marketplace. There were wooden buildings in villages of the local population in which one village was on the right bank of the Daugava, but the other - at the mouth of the Riga River. In the $12^{\text {th }}$ century, an international market was at Riga butfive large groups ofLivonian settlements formed anurban complex in the Lower Daugava area.Each of the centres had a hill-fort and several ancient towns.On a high dolomite rock on the right bank of the Daugava, where the Rumbina River flows, Dievukalns Hillhas been populated by the Livonians of Lielvārde since the $9^{\text {th }}$ century. An ancient 
town developed at the foot. Eastwards of Lielvārde, significant traffic routes intersected in the central part of the Principality of Koknese. Centres in early administrative units created by the Latgalians around the year 900 were closely connected and did not exist in themselves. The political, administrative and economic centre of Kukonoyse(Latvian: Koknese; $11^{\text {th }}-12^{\text {th }}$ cent.) located on a dolomite rock between the Përse River deep ravine by its estuary and the ancient bank of the spacious Daugava Valley opposite the 18-metres high river cliff of Staburags. The Latgalians, the Selonians, the Krivichs and members of other ethnic groups lived in an ancient town and practisedin crafts and developed trade relations.

German merchants arrived at the local people Livonian-inhabited Baltic Sea coast to monitor the highway. In 1201, they began to form the Old Town of Riga covered by a street semicircle and divided into four parts. A wide street led to the waterfront, but on the other main street parallel to the Riga River, semicircle quarter took the bishop's first yard (1201-1215) with St. Mary (Latin: eccesia beate Marie) Cathedral mentioned for the first time in 1206. Next to which the Livonian Brothers of the Sword created the yard. In towns founded by German traditions, churches for citizens' Catholic parishes were built. In Riga, on the hill at the crossroads of streets (Fig. 1), St. Peter's Church was built, but a marketplace and wooden living houses were built nearby. The Great Sandy Road from the marketplace went to the central gate and behind it provided Riga by road traffic. The Germans established centres of secular and spiritual power in Riga, political and economic dualism and the main military-economic base for expansion in the Baltics. Riga got an urban solution specific to Christians. The fortified Old Town of Rigahad a layout similar to Jerusalem, where the CardoMaximus crossed at right angles the Decumanus Maximus. The town of four-part layoutacquired a functionally based scheme divided into quarters. Conquerors invaded one of the largest settlements on banks of the Daugava and the Livonian Brothers on the Latgalian hillfort built one of the first Riga Bishop's residences of dolomite - the castrum Kukonois (Kocanois; 1209) of irregular planning.

In the second stage of Riga's development by the year 1210, the back of the fortified small semi-circular town of the German immigrants has access to the Riga River. Soon after 1211, the city was extended to the Daugava. Outside the city wall, on 25 July 1211, Bishop Albert consecrated the building site of the monastery of St. Mary's Church. In 1215, a great fire broke out in the fortified Old Town. In the third stage of Riga's development until 1220, earth roads formed the basis for the street network in the city, whose centre building consisted of a monumental complex, but the concentration of three competing forces on a small plot of land proved to be problematic- armed conflicts turned out. Soon after the great fire, market place (later Town Hall Square) was created in the New City (civitas nova), which was first mentioned in documents in 1220. In the New Town 
of Riga (in nova civitate Rige), the construction of the second cathedral and residence of the bishop began. Protective walls were no longer able to protect the city, and the expansion of Riga's borders became topical. The second protective wall around 1225 covered the suburb. In the enlarged city area, the fortified Old Town was also included. Riga ended in 1225 the stage of development in which the city gained formal autonomy. In Eastern Europe, Riga became an important Archbishopric and Christianity centre.

Assessing the European context, a common feature for the Riga Cathedral (Fig. 2), which became the main building in the Riga Archbishopric, in whose subjugation seven bishoprics got, was the ability to organize urban environment in an architecturally active way. A distinctive feature was the structural construction of the Christianity centre - mutual correlation between the Canonical Chapter and Bishop's Residence - two urban building structures, related to the cathedral. The building complex of the Riga Archbishopric Centre consisted of two yards - the bishop's yard with a perimeter building and the Canonical Chapter's yard with the monastery, in which the cathedral was included. The layout of the Riga Cathedral and monastery buildings were traditional: the cathedral with the tower, crowned by a slender spire, situated in the north, but monastery buildings - in the south.

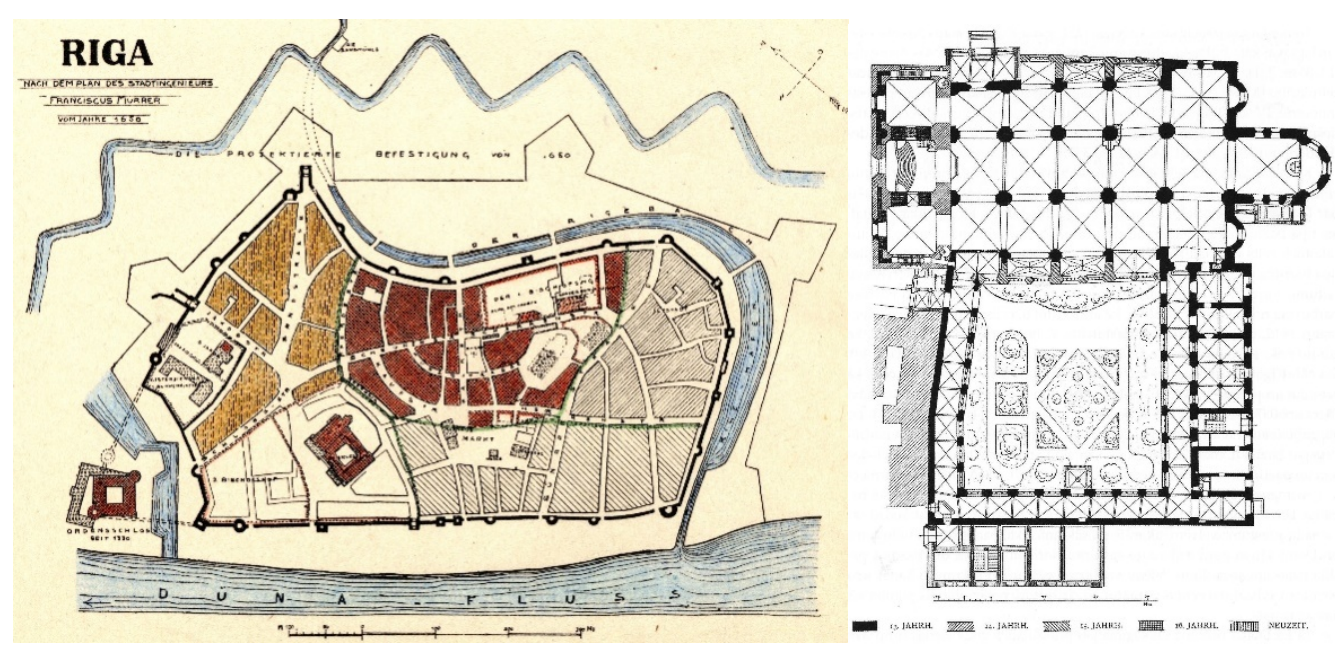

Figure 1 Plan of Riga. 1650 (stored at the University of Latvia Academic Library, formerly Library of Misins)

Figure 2 Architect Johann Wilhelm Carl Neumann (1849-1919). Plan of Riga Bishop's second Cathedral and monastery. 1912 (Neumann, 1912)

At the crossing of the Daugava Waterway and earth roads, the urban planning of the Old Town of Riga was defined by the cross of two main streets emphasized by St. Peter's Church for citizens' Catholic parish. The urban planning of the New Town of Riga created by two urban structures of the 
Archbishopric Centre - the perimeter building of Riga Bishop's second yard by sacral structures - reminded of the solution for Roman Bishop's Residence on the Caelian Hill in Rome, and the building complex of Riga Canonical Chapter's yard consists of the Riga Cathedral included in the monastery complex built according to the Cistercian monastery's functional scheme developed by Bernardus Claraevallensis. The city's central part was accentuated by the Riga Cathedral, in which planning and architectural solution in the course of construction were changed according to the latest trends in cathedral construction.

Around 1400, Riga as an important trade and crafts city in Eastern Europe, and the Archbishopric Centre had planning created by fortified yards of residences, trade and cult buildings close to city's defensive wall. In the international market place, sacral space of the Christianity centre was connected by concepts the Place, the Way and the Symbol.

\section{The Cosmology of Sacral Buildings}

In the past, knowledge of earth energy used in church construction. The altar was made in a harmonious place where one feels well. On 25 July 1211, the place outside the city's walls was consecrated, and construction of the Riga Cathedral (Fig. 3) on the bank of the Daugava River began. It was not possible to implement quickly the large-size pillar basilica in the newly founded Bishopric of Riga. The presbyterium and the transept of the Riga Cathedral were finished in 1220. After the cathedral was fully built, a Christianity centre was created to promote the discovery and spread of Christian values of Western Europe on the Baltic southeastern coast.

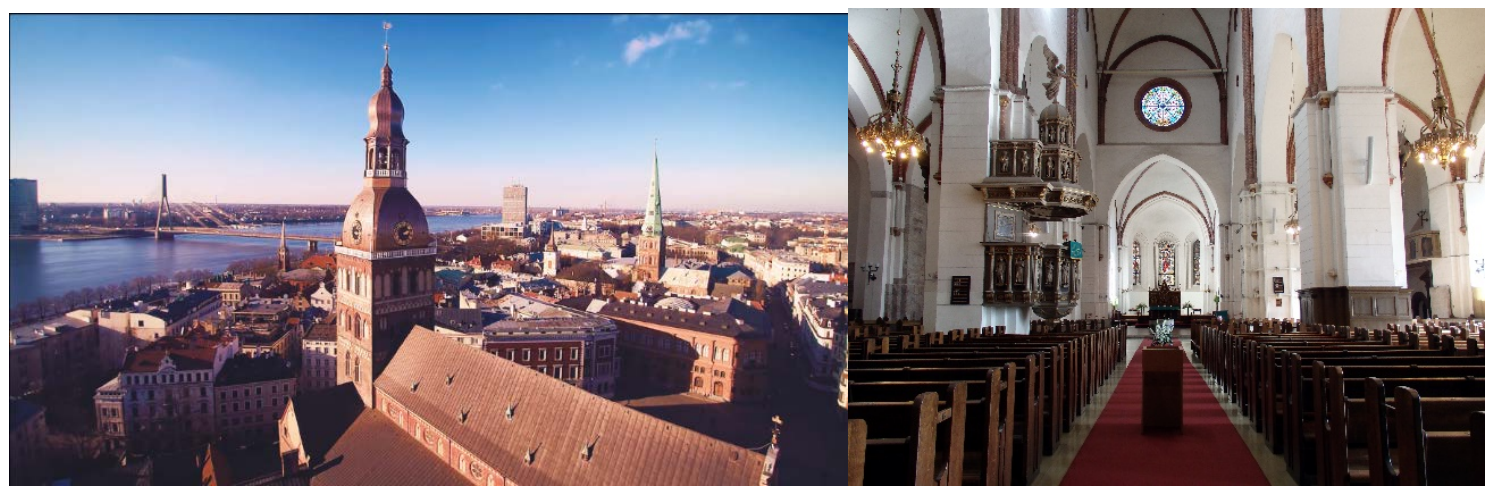

Figure 3 Panoramic view of Riga Cathedral (online 28.02.2020, source https://www.arcers.lv/images/newnewscollection/sik_6.png)

Figure 4 Interior view of Riga Cathedral (online 28.02.2020, source https://upload.wikimedia.org/wikipedia/commons/4/42/R\%C4\% ABgas_Doms_\%2874\%29.JPG) 
The Riga Cathedral of the Latin cross layout has the choir square and a semicircular apse, the eastern transept and a massive volume on the west side. The three-nave congregation room has four bays. Its planning is close to a square and creates outlines typical to a hall-type building (Fig. 4). Massive pillars of a crosstype planning mark borders between the middle nave and side naves. Buildings of an abbey locate at the end wall of the transept on the south side of the cathedral, and the square yard is surrounded by three cloister blocks. Presumably, on the west façade of the Riga Cathedral, there is the initial entrance with a semicircle covering. Nevertheless, the portal of the main entrance has been made on the north side. It could be related to the desire to make the church more accessible to the newly-founded city, to which the north façade of the Riga Cathedral was turned. The layout of the Riga Cathedral and monastery buildings is traditional: the cathedral with the tower, crowned by a slender, tall spire, located in the north, but monastery buildings - in the south. The Riga Cathedral is one of the oldest sacred buildings of the medieval period in Latvia and also the Baltics. During the Soviet occupation from 1939 to 1989, religious services were prohibited.The cathedral from 1959 to 1962 was adapted for playing music and used as a concert hall.

On 4 May 1990,the Declaration "On the Restoration of Independence of the Republic of Latvia" was adopted and the restore process of an independent Latvia began. A very short period before Latvian independence was restored, the singing of "Dievs, svêtī Latviju!" /God Bless Latvia!/, banned during the annexation of Latvia by the Soviet Union, was restored on 15 February 1990 as the state anthem of Latvia. The music and lyrics in 1873 were written by teacher Kārlis Baumanis (also Baumanu Kārlis; 1835-1905).With the restoration of the Republic of Latvia, the Cathedral of Riga in 1991 became available to the Latvian Evangelical Lutheran Church.

In January 1991, the central power in Moscow started military actions, to renew its influence in the Baltics. Latvia declared the restoration of independence from the Soviet Union a year earlier, anticipated that the Soviet Union might attempt to regain control over the country by force. In Riga on the evening of 20 January, the firing of the Interior Ministry started and continued in the Old Town. The people of Latviagathered in Riga Cathedral Square located in the very heart of Old Riga.The Riga Cathedral for centuries has been the place where people have sought to meet God, and during the bloody events, it was open to anyone who seeks himself, seeks the truth, seeks God, seeks men community. People agreed on common prayer, cared for the wounded, placed the dead, and in the cathedral, an important holy place, the people and the divine world communicated between each other. Now the Riga Cathedral is not only the Evangelical Lutheran cathedral and the seat of Archbishop of Riga and Latvia and the parish church of Dome, but also the Place became the Simbol and where the Way to the restoration of independence of the Republic of Latvia began. 


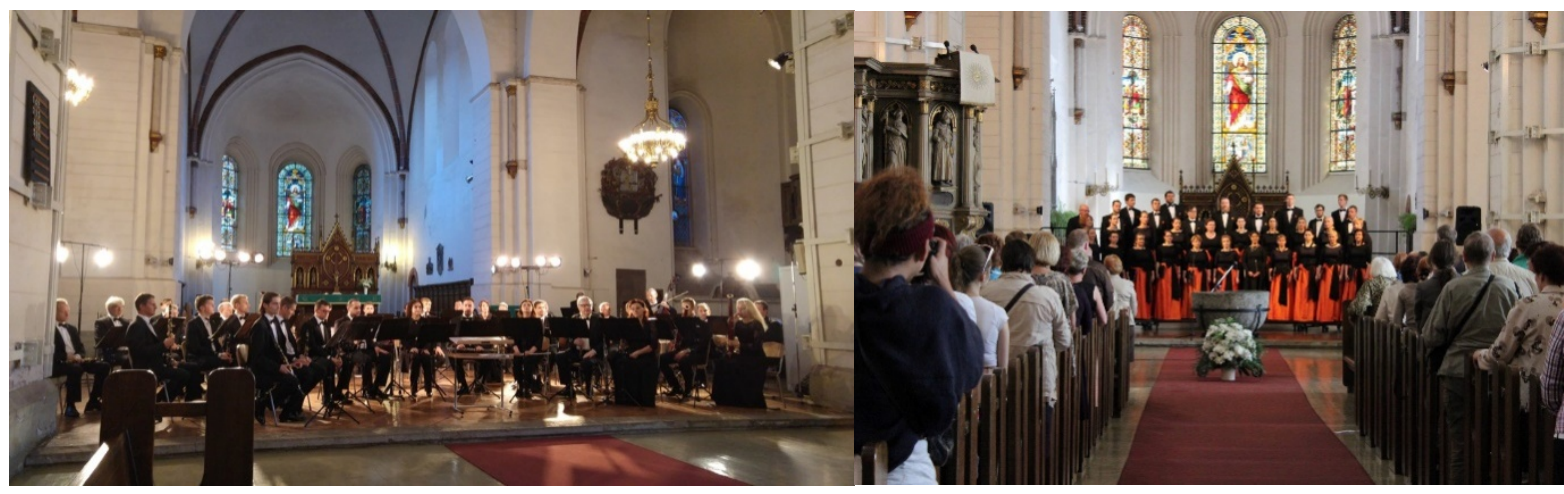

Figure 5 Orchestra at Riga Cathedral (online 28.02.2020, source http://muzikaspasaule.lv/images/News_Images/O/OrkestrisRiga/OrkestrisRigasDoma.jpg)

Figure 6 Choir at Riga Dome Cathedral (online 28.02.2020, source http://www.palliative.lv/wp-content/uploads/2016/05/koris.jpg)

Each cathedral is unique. Dr Nicolas Reeves and his colleagues David StOnge, MSc, Ph. D at École Polytechnique de Montréaland Pierre-Yves Brèches McGill Universityused an interactive sound installation that transposes architecture of the Mende Cathedral into sound timbres and music, through a method using a mathematical object called "spherical harmonics". It can be seen as a contemporary and poetic version of the harmony of the spheres, revisited in the light of current models from fields of music, acoustics and astrophysics (Reeves, 2017). Any architecture is as a small interpretation of cosmology, but the Riga Cathedral is an important sanctuary in the Baltics, and in it, orchestra plays compositions (Fig. 5), whose spiritual value corresponds to the status and traditions of this cathedral. Closely related to Riga is the name of Richard Wagner, who from 1837 to 1839 was a conductor at the Riga City Theater.The energy of the holly place maintained by Johann Sebastian Bach's (1685-1750) spiritual melodies played on the cathedral organ providing the connection with the Heavenly world, as well aschoral songs (Fig. 6).

\section{Generative Creating of Contemporary Sacral Cpace}

A Spanish surrealist artistSalvador Dalí (1904-1989) utilized his theory of "nuclear mysticism", a fusion of Catholicism,mathematics and science, to create this unusual interpretation of Christ's crucifixion. Dali's image of the crucified Christ (Fig. 7) represents the search for the transcendental or fourth dimension. Levitating before a hypercube as a geometric, multidimensional form Christ's body is healthy and athletic and bears no signs of torture. The crown of thorns and nails are missing. The artist's wife, Gala, poses as a devotional figure, witnessing Christ's spiritual triumph over corporeal harm. Several dreamlike elements from 
Dali's earlier surrealist work feature in this painting: a levitating figure, vast barren landscape and chessboard.

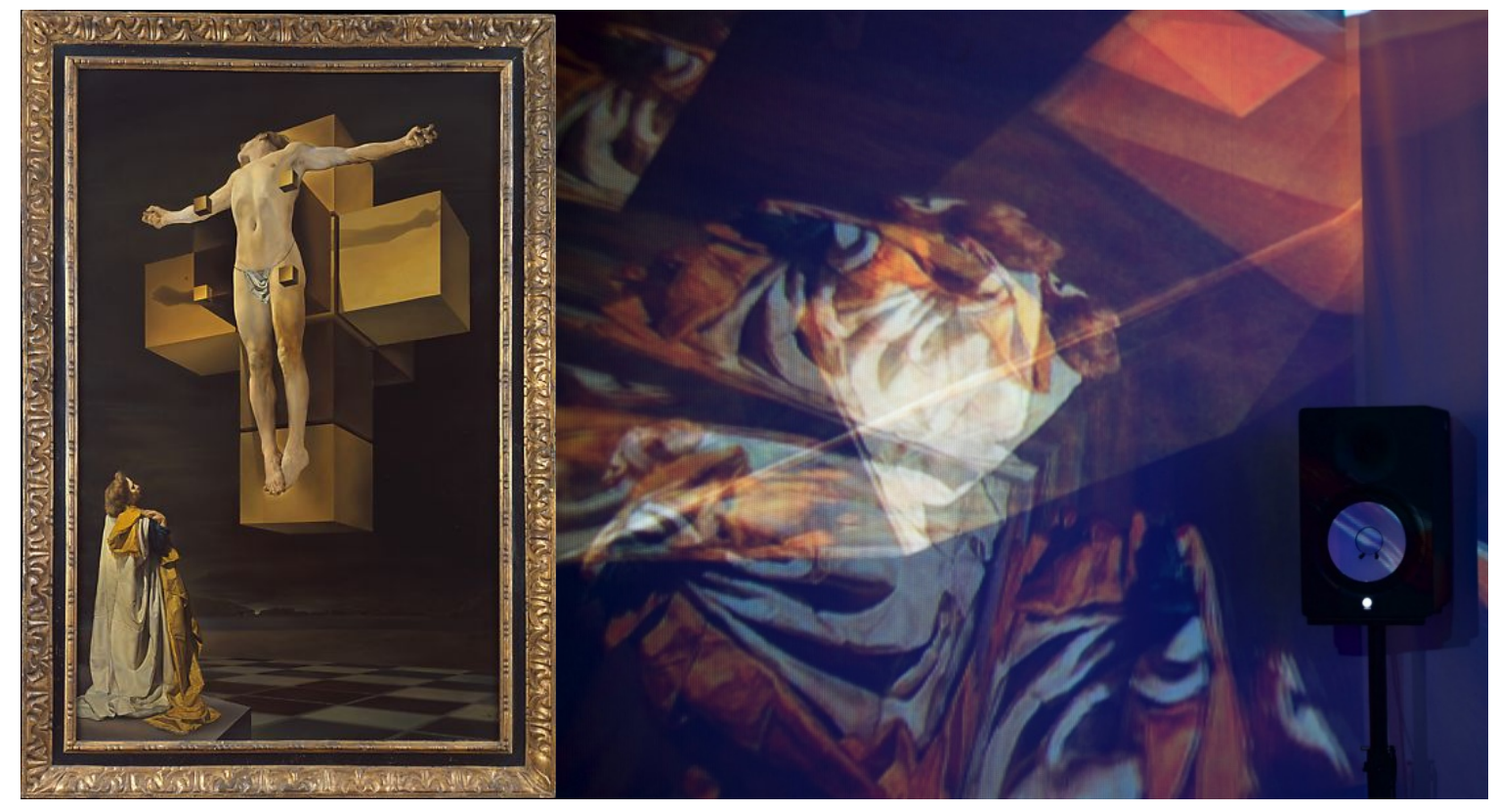

Figure 7 A Spanish surrealist artist Salvador Domingo Felipe Jacinto Dalí i Domènech (1904-1989). Crucifixion (Corpus Hypercubus). 1954 (online 17.05.2019, source: https:// collectionapi.metmuseum.org/api/collection/v1/iiif/488880/1005811/restricted)

Figure 8 Professor Jônatas Manzolli. Photo of the animated collage generated during the performance of the Ode(Manzolli, 2018, 177)

Professor of the University of Campinas (Brazil) Jônatas Manzolli gained a Degreein Mathematics (1983) and Music Composition (1987) from UNICAMP now studies Arts and Technology relationship in music creation. He is the coordinator of NICS - Interdisciplinary Centre for Sound Communication and special attention paid to the synthesis of architecture, art and music. His work includes instrumental and electroacoustic pieces, music for dancing and sound installations. A creative process of the Ode to Christus Hypercubus aided by computer involving music, images and poetry. The Ode to Salvador Dali's Christus Hypercubus (Fig. 8) reported as a multimodal performance fulfils the sound space with alterations of sacred music. It consists of images and music that interacts with live musicians and a virtual choir in real time. A diffused acoustic field generated with fragments of sacred music invites the audience to rediscover and recreate meanings for the Catalan's masterpiece. The computer system orchestrates 16 compositions in miniatures called "stanzas of the Ode". The poem "Caminho da Espera" written by the author provides lyrics for excerpts from three sacred works: “Ave Maria Stella” by Perotin (1200-1225), a European composer who is believed to be French, "Benedictus” by Portuguese composer Frei Manuel 
Cardoso (1566-1650) and "Sepulto Domino" by the Brazilian composer Father José Mauricio Nunes Garcia (1767-1830) who constructs the Medieval Organum as a metaphor of an imaginary echo that still has persisted in walls of cathedrals. A constant musical drone accentuates resonances in which memory is expanded into fragmented chants that still linger on walls and in arches. The idea is to simulate fourth-dimension Hypercubus using the audio signal to produce 3D transformations. The program extracts pitch and intensity from the audio signal and animates the four cubes in real time iteratively. Images are generated along with sounds in real time; see the visual result in images below. Using interactive techniques derived from computer-aided real-time composition, the Ode attempts to explore human cognition and understand how creativity operates in a multimodal environment. Multimodal generative installations can be seen as a way to create a unified experience where sound, image and audience are merged in space and evolve coherently in time and to explore both implicit and explicit cues in their individual and collective interaction and to boost interaction with audio-visuals generated during the man-machine interaction, as discussed in (Manzolli, 2018, 171). Sacral space, important for the spiritual growth and perfection of modern man, does not have any nationalities.

The aesthetically aggressive, over-urbanized, technology-influenced functional environment puts heavy psychological adaptation demands on people. A person as an integral part of nature and a person as an integral part of an artificial environment is in a deep internal conflict that can be solved by balanced action. The environment needs to be humanized. A person must change his attitude towards himself and nature. There is a need to change the current understanding and thinking of the world. In the age of globalization, human affection for a particular denomination is not emphasized.

In a generative process, poetic logic is the art of connection between a past and a future time, but the main procedure is to identify a performing aim as a character which is able to delineate an unstable system between imaginary and real constraints (Colabella, 2013, 108). We need a structure of connection, not deductive but abductive: the only one able to perform a nonlinearity following an interpretation (Colabella, 2015, 65).

"Nowadays, the world has very nice directions of church architecture development, determined by Scandinavians-Norse, the Swedes, the Finns. Combination of modern technology and design with a traditional or quite innovative space planning produce a solution with some original features, can become especially sacred, and create an atmosphere of reverence no worse than it has been for centuries. In the landscape of Finnland, churches surrounded by forest and the river bay often are seen, but even it is cut in the rock. I see the ability of modern Finnish architects to feel nature of their homeland, environment and culture very deeply, but at the same time - do not lose respect for the Christian 
culture, the substance of which they try to put in modern architecture. In Australia, America and England, where congregations' material wealth allows you to attract the world well-known architects, I have seen postmodern, brilliantly luxurious worship spaces, what in expensive materials have got developed to refinement. In such cases, the congregation is aware goals, what puts it on itself - to create a material value that can also become symbolic, and about which the whole country would talk. This is the task of architecture - to create a step, on which the future architecture or the fashion wave would be the starting point. An example of postwar England architecture was the Nazi ruined, but now modern Coventry Cathedral," scientist, academician and Professor of the Art Academy of Latvia Dr Hab. Art. Ojārs Spārītis tells us. These are different orientations, among which Latvia is forced to carry out its search today. These searches take place among the Lutherans, the Orthodoxians and the Catholics. The Orthodox believers wear their traditional culture and that, what this confession was caused by the Soviet era and taken away (Spārītis, 2015, 190). Where to develop church architecture in Latvian Lutheran and Catholic space? Catholics in Latvia are open for experimentation; they are acting much and energetically and are not afraid to make mistakes (Spārītis, 2015, 193). I would like them to think before they made a mistake could it not be avoided?

The Latvians, discovering the historical heritage, find interesting solutions to increase the informative emotional potential of the environment and the artistic expression of urban space to preserve identity. After World War I, in the Republic of Latvia, studies of ethnography, archaeology, history, geography and the development of settlements became topical. Dean of the Faculty of Architecture of the University of Latvia, architect Professor Eižens Laube (1880-1967), focused on Latvian material culture and architecture research because it was indispensable to develop architecture characteristic for Latvia. The essence of Latvia must be understood deeply and wide in order to build fits in Latvian peculiar physical and spiritual environment. There are very much but even conflicting manifestations of Latvianbeauty: the definition of Latvian beauty is not and not be able a single.

On an island on the Daugava River, there is a place near the ancient town of Koknese where the past, the present and the future of the nation merge to give solace to the past, strength to the present and inspiration to follow your dream in the future. The architectural ensemble of monumental landscapes till the 100th anniversary of the Proclamation of Independence of Latvia on 18 November 2018 was created. Landscape artist Shunmyō Masuno from Japan in cooperation with “Japan Landscape Consultants” Ltd. and Latvian architects Andris Kronbergs and Raimonds Saulitis along with the design bureau "ARHIS" and the people of Latvia are all helping to implement a dream - the Garden of Destiny created for the memory of all the inhabitants whom Latvia lost during the twentieth century, 
the ones who perished in wars, the repressed one and the ones who were forced to go to exile or suffered any other way due to their political views. The Garden of Destiny as a whole is like a symphony - it consists of the prelude and six parts, which symbolizes harmony and eternity of nature and the human being. Each part is divided into three zones, but each zone is related to its Time and Space. All in all, it symbolizes eternity. The first is the "Zone of Memory" which is orientated towards the past and consists symbolically of two parts. The first part "Promise" or "Silver Sunset" starts with a stone paving, followed by a water canal, or the River of Tears (Fig. 9), which flows along the external side of the stone layer and symbolizes victims' tears and faith that what happened in the past will never ever recur. A monument hill made of 600,000 grey stones which were taken there by inhabitants of Latvia for their relatives and family remembrance. The sunset is not in the usual colour but rather grey - as a tragedy and emotional experience about what has happened. The central part has a bizarre-shaped pond with islands surrounded by man-made hills and valleys, along which travel routes are laid. To arrive in the heart of the Garden of Destiny, one has to let the river with its eternal and soothing water flow to find consolation. The second part is "Prayer" or "Light of Soul". In the place where we pray so that what happened to us would never ever repeat again, one can watch the sunset in the evening. The second one is the "Healing Zone" dedicated to the future. The third zone is the "Destination Latvian's Heart”.

Plants are the flesh of any garden. In the Japanese garden, preference is always given to native species of trees, shrubs and grasses. The main structural tree is a pine - a symbol of happiness and longevity. Plants are often used as carriers of a symbolic load, closely related to spiritual and physical life. The garden teaches suchness or the intrinsic value of each thing, connectedness, harmony, tranquillity and sacredness of the everyday. Developing a sense of respect for all things is no small step in becoming an ethical human being, both with respect to other humans and the environment at large. A garden is not so much a place for pleasure, recreation or socializing, as a way to achieve a certain state of the human spirit, peace of mind and balance of consciousness. In the Japanese garden, preparation for it begins. Elements for landscape design are secondary to invisible philosophical, religious and symbolic elements - water, stone islands, plants and traditional small forms. Any element very rarely carries any additional, symbolic load, but then especially high aesthetic requirements are placed on it. The refined simplicity of things has the strongest artistic impact on the audience. A garden should occupy a large area in which we travel through time and space. In the garden, we do not walk but travel along roads and do not wander without a goal but move from place to place and from discovery to discovery. In Japan, time is always considered the co-author of the garden and the assistant designer. Develop a garden so that its beauty responds to the place and 
course of time, as leaves respond with a breath of breeze so that there is nothing bulky and coarse in it. Instead of absolute dimensions, the consciousness and the subconsciousness are completely affected by the "three forces": horizontal, vertical and inclined planes. We react to each of them in a completely different way: the horizontal is associated with the earthly expanse or a water mirror, with a calm, slow motion and, consequently, spiritual tranquillity. The vertical is the tension and energy needed to move up to the sky, but a clean, accented vertical is quite rare in a Japanese garden. The diagonal, or inclined plane, most often in form of an old tree, bent under the weight of years or slopes with stone debris and bistro running streams causes dynamic associations. The result of creative and hard work should look easy and at ease as a result of the work of the genius of nature and not of human hands.

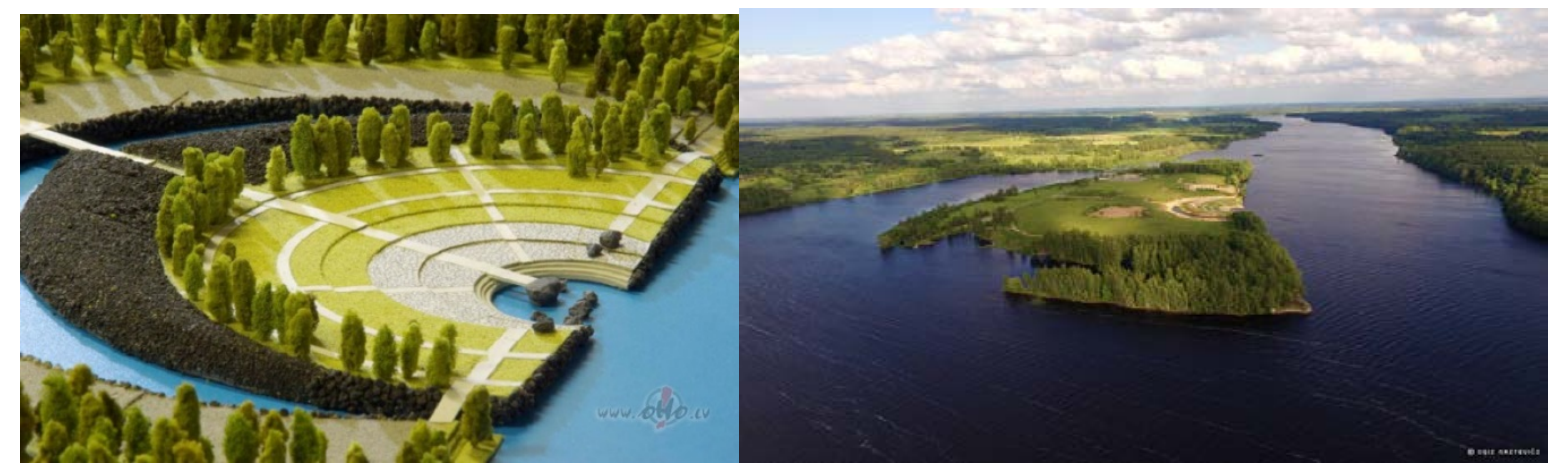

Figure 9 Landscape artist Shunmy $\overline{\bar{o}}$ Masuno. The model of the garden of destiny (online 02.08.2017, source: $h$ ttp://www. alausa.org/media/files/infogram-sep-2015/liktendarzs.jpg)

Figure 10 Photographer Ugis Nastevičs. The garden of destiny on the island in the

Daugava River - a place near Lielvärde and the Castle of Koknese (online 02.08.2017, source: http://i9.tiesraides.lv/1200x0s/ pictures/2016-07-25/2016-07-

25_liktendars_ugis_nastevics.jpg)

The Garden of Destiny is a symbol, created in nature for constant renewal and growth of the nation - here the past, present and future of both the human and the state meet. An outstanding environmental architecture with nature of the island and beauty of the Daugava's flow has been combined. The Garden of Destiny opened on 11 August 2018 gives joy on blue waters of the Daugava and changeable gradations of the sky (Fig. 10) (Ozola, 2018).

Italian architect, Professor Celestino Soddu considersthat the city is a collective dream of which we don't know the end but only as it is running. This city-Idea transforms itself in progress by building an urban identity and uniqueness that we can identify as a peculiar way of looking to the future (Soddu, 2016, 15). 


\section{Conclusions}

1. Riga became the center of Christianity in the $13^{\text {th }}$ century, a sacred environment was created, and its main building was a cathedral.Interior synthesized different kinds of art was man-made environment with cosmicelements for communication with God andprayer for dialogue with higher powers andreligious ritual.This place, where the synthesis of architecture and art acquires perfection, is important for people to find peace, regain hope and faith.

2. The $21^{\text {st }}$ century represents the active practice of generative creating of modern sacral space and represents a new step in the development of a specific sacred environment and design. A complex multistage process of collective creativity is characterized by a way of looking to the future. It makes a conclusion that the use of the artistic experience of the past is the leading tendency in the development of modern monumental sacral space. Nowadays, using the generative creating, latest technologies and international cooperation, the sacral space made up in Christian traditions is in the natural environment as well as in the urban environment. The generative creating of sacral space for religious ritual today also is connected by concepts the Place, the Wayof spiritual growthand the Symbol.

\section{References}

Colabella, E. (2013). Imaginative constrains for generative chain. In XVI Generative Art Conference Proceedings. Milan: Domus Argenia Publisher, 104-113.

Colabella, E. (2015). Poetic logic. In XVIII Generative Art Conference Proceedings. Milan: Domus Argenia Publisher, 65-80.

Manzolli, J. (2018). Multimodal architecture of the Ode to Christus Hypercubus. In XXI Generative Art Conference Proceedings, Milan: Domus Argenia Publisher, 171-182.

Neumann, W. (1912). Der Dom zu St. Marien in Riga. Riga: G. Löffler.

Ozola, S. (2018). Latvian garden of destiny- the place for inspiration to implement dreams. In XXI Generative Art Conference Proceedings, Milan: Domus Argenia Publisher, 397-414. Reeves, N. (2017). Origin point: harmonic echoes of mineral cosmology (Mende Cathedral). In XX Generative Art Conference Proceedings, Milan: Domus Argenia Publisher, 288-319. Soddu, C. (2016). The discovering persistent deep memory in generative design. In XIX Generative Art Conference Proceedings, Milan: Domus Argenia Publisher, 15-35.

Spārītis, O. (2015). Esejas par Latvijas sakrālo kultūru. Rīga: Jumava. 